\title{
PENGARUH PEMBERIAN SUMBER SERAT BERBEDA DALAM PAKAN TERHADAP KECERNAAN SEMU SERAT KASAR DAN HEMISELULOSA PADA AYAM PEDAGING STRAIN COBB
}

\author{
Yasinta Y.A. Sasae, J.J.M.R. Londok*, B. Tulung, C.A. Rahasia \\ Fakultas Peternakan Universitas Sam Ratulangi Manado
}

\begin{abstract}
ABSTRAK
Penelitian ini dilaksanakan dengan tujuan untuk mengetahui pengaruh pemberian sumber serat yang berbeda dalam pakan terhadap kecernaan semu serat kasar dan hemiselulosa pada ayam pedaging strain cobb. Penelitian ini menggunakan 20 ekor ayam pedaging strain Cobb berumur 35 hari. Rancangan yang digunakan adalah Rancangan Acak Lengkap (RAL) dengan perlakuan 4 sumber serat berbeda dalam pakan yang diulang 5 kali. Perlakuan terdiri atas: R0 (pakan komersial), R1 (pakan komersial dengan kulit kopi), R2 (pakan komersial dengan dedak padi), dengan R3 (pakan komersial dengan ampas kelapa). Peubah yang diukur yaitu: kecernaan semu serat kasar dan hemiselulosa. Pengukuran kecernaan semu menggunakan metode total koleksi. Data dianalisis menggunakan ANOVA, selanjutnya perbedaan antara perlakuan diuji dengan BNJ. Kecernaan semu serat kasar pakan berpengaruh sangat nyata $(\mathrm{P}<0,01)$ oleh sumber serat. Kecernaan semu hemiselulosa pakan menunjukkan pengaruh yang nyata $(\mathrm{P}<0,05)$. Uji BNJ dari kecernaan semu serat kasar menunjukkan bahwa R0 sama dengan R3, namun berbeda sangat nyata $(\mathrm{P}<0.01)$ dengan perlakuan $\mathrm{R} 2$ dan $\mathrm{R} 1$. Perlakuan R2 berbeda tidak nyata $(\mathrm{P}>0.05)$ dengan R1. Uji BNJ kecernaan semu hemiselulosa menunjukkan bahwa R3 sama dengan R0, namun berbeda sangat nyata $(\mathrm{P}<0.01)$ dengan perlakuan $\mathrm{R} 2$ dan
\end{abstract}

\footnotetext{
* Korespondensi (corresponding author)

Email: jolalondok@unsrat.ac.id
}

R1. Perlakuan R2 berbeda tidak nyata ( $\mathrm{P}>0.05)$ dengan perlakuan $\mathrm{R} 1$. Disimpulkan bahwa ampas kelapa sebagai sumber serat dalam pakan ayam pedaging strain cobb memberikan kecernaan serat kasar dan hemiselulosa yang lebih baik dibandingkan dengan sumber serat kulit kopi dan dedak padi.

Kata Kunci: Kecernaan semu serat kasar, Kecernaan semu hemiselulosa, ayam pedaging strain cobb

\begin{abstract}
THE EFFECT OF DIFFERENT FIBER SOURCES IN THE FEED TO DIGESTIBILITY OF CRUDE FIBER AND HEMICELLULOSE IN COBB STRAIN OF BROILERS. This research was carried out with the aim to determine the effect of providing different sources of fiber in feed on the apparent digestibility of crude fiber and hemicellulose in cobb strain of broilers. This study used 20 cobb strain of broilers 35-day-old. The design used was a Completely Randomized Design (CRD) with the treatment of 4 different fiber sources in the feed which was repeated 5 times. The treatments consisted of: R0 (commercial feed),R1 (commercial feed with coffe skin), R2 (commercial feed with rice bran), R3 (commercial feed with coconut pilp). Variables measured were: apparent digestibility of crude fiber and hemicellulose. Apparent-digestibility measurements using the total collection method. Data were analyzed using general
\end{abstract}


linear model (MINITAB version 16), then differences between treatments were tested with Tukey's simultaneous test. Apparent digestibility of crude fiber feed has a very different $(\mathrm{P}<0,01)$ with treatment $\mathrm{R} 2$ and $\mathrm{R} 1$. The treatment of $\mathrm{R} 2$ was not significantly different $(\mathrm{P}>0,05)$ from $\mathrm{R} 1$. Apparent digestibility test for hemicellulose shows that R3 is the same as $\mathrm{R} 0$, but it is significantly different $(\mathrm{P}<0,01)$ with treatment $\mathrm{R} 2$ and $\mathrm{R} 1$. The treatment od $\mathrm{R} 2$ was not significantly different $(\mathrm{P}>0,05)$ from the treatment of $\mathrm{R} 1$. It was concluded that coconut pilp as a source of fiber in the feed of strain cobb of broilers provides better digestibility of coarse and hemicellulose fibers than coffe huks and coffe bran

Keywords: Apparent digestion of crude fiber, Apparent digestion of hemicellulose, strain cobb of broiler

\section{PENDAHULUAN}

Sektor perunggasan di Indonesia merupakan pilihan tepat untuk dikembangkan khususnya ayam pedaging yang dapat memenuhi kebutuhan protein hewani, karena pertumbuhan yang cepat, tidak membutuhkan banyak tempat dan biaya pemeliharaan yang relatif murah, dibandingkan dengan ternak besar. Ayam pedaging telah mengalami seleksi gen bertahun-tahun sehingga pertumbuhannya sangat pesat, dalam waktu 29 sampai 30 hari sudah bisa dipanen. Ayam pedaging juga dibedakan dengan strain. Strain adalah merek dagang hasil seleksi breesing untuk tujuan tertentu. Tujuannya untuk komersial atau nilai ekonomi, dimana strain Copp merupakan galur murni yang unggul dan sangat peka terhadap perubahan dan lebih selektif (Muhammad, 2014). Sehingga faktor yang sangat mempengaruhi pertumbuhan atau produktivitas ayam pedaging adalah pakan. Kecepatan pertumbuhan ayam pedaging dapat tercapai apabila pemeliharaan dan pencegahan penyakit dapat ditangani dengan baik. Produk ayam pedaging sebagai sumber pangan hewani memberikan kontribusi yang tidak kalah penting dengan daging lain bagi konsumen Indonesia. Usaha peternakan ayam pedaging sangat prospektif untuk dibudidayakan dalam skala besar.

Pemberian pakan untuk ayam pedaging juga mempunyai pengaruh yang besar untuk pertumbuhan ternak, namun bahan pakan yang berkualitas bauk seperti jagung dan bungkil kedelei memiliki harga yang relatif mahal dan masih bersaing dengan kebutuhan manusia sebagai pangan. Sebab itu dibutuhkan pakan alternatif yang lebih murah dan boleh dijangkau oleh para peternak. Pemanfaatan limbah pertanian menjadi jalan keluar untuk para peternak sebagai pakan alternatif seperti pemanfaatan limbah kulit kopi, dedak padi dan limpah ampas kelapa. Dimana limbah kulit kopi bisa menggantikan jagug dan 
amps kelapa bisa memiliki fungsi menyehatkan alat pencernaan ternak. Namun, kurangnya pengetahuan para peternak tentang serat kasar sehingga bahan-bahan pakan tersebut masi jarang digunakan dan dimanfaatkan oleh peternak di Indonesia sebagai pakan untuk ternak. Sehingga dilakukan penelitian dengan memberikan pakan dengan sumber serat yang berbeda pada terrnak karena pakan yang mengandung serat kasar itu memiliki fungsi untuk mempercepat atau merangsang gerakan peristaltik di dalam usus sehingga makanan yang ada di dalam usus lebih cepat dicerna, tanpa bantuan serat makanan dengan kandungan air rendah akan lebih lama tinggal dalam saluran usus dikarenakan gerakan peristaltik usus besar menjadi lebih lamban. Serat juga memiliki peran yaitu kemampuannya untuk mengikat air.

Serat dibedakan menjadi dua yaitu serat kasar (crude fiber) dan serat makanan. Serat kasar dibutuhkan ternak non ruminansia sebagai pemacu kerja dari alat pencernaan, dimana pada batas-batas tertentu dapat mencegah terjadinya pengumpulan makanan pada saluran pencernaan. Serat kasar suatu bahan pakan sangat mempengaruhi kecernaan pakan, baik dari segi jumlah maupun dari komposisi kimia atau komponen seratnya. Serat makanan adalah bagian dari bahan yang tidak dapat dihidrolisis oleh enzim- enzim pencernaan. Mutu serat dapat dilihat dari komposisi komponen serat makanan, dimana komponen serat makanan terdiri dari komponen yang larut (soluble dietary fiber, SDF) dan komponen yang tidak larut (insoluble dietary fiber, IDF). Serat yang tidak larut dalam air 3 macam yaitu selulosa, hemiselulosa, dan lignin. Serat yang tidak larut memiliki fungsi penting dalam saluran alat pencernaan. Tingginya daya mengikat air (high water binding capacity) pada serat dapat memperbesar volume makanan yang sudah bercampur saliva dan enzim dalam saluran alat pencernaan dan akan meningkatkan gerak peristaltik usus, serta mempercepat perpindahan sampai di kolon. Serat yang larut dalam air seperti pektin, bisa mensuplai nutrien untuk mikroba kolon, seperti asam-asam lemak rantai pendek (asam asetat, propionat dan butirat) yang pada gilirannya berkontribusi untuk stabilisasi mikroba kolon dan menurunkan resiko translokasi bakterial.

Kecernaan suatu bahan merupakan bagian yang tidak diekskresikan dalam ekskreta dan merupakan pencerminan dari tinggi rendahnya manfaat bahan pakan tersebut. Kecernaan dipengaruhi oleh beberapa faktor yaitu: tingkat pemberian pakan, spesies hewan, suhu, laju perjalanan makanan melalui alat pencernaan, bentuk fisik makanan, komposisi pakan dan kandungan serat kasar dalam pakan. 
Berdasarkan uraian di atas maka dilakukan penelitian dengan tujuan untuk melihat pengaruh pemberian sumber serat yang berbeda dalam pakan terhadap kecernaan semu serat kasar dan hemiselulosa pada ayam pedaging strain Cobb.

\section{MATERI DAN METODE PENELITIAN}

\section{Waktu dan Tempat}

Penelitian dilaksanakan di kandang percobaan unggas Fakultas Peternakan Universitas Sam Ratulangi Manado. Penelitian berlangsung selama 10 hari, 7 hari pendahuluan dan 3 hari pengumpulan data.

\section{Materi Penelitian}

Penelitian ini menggunakan 20 ekor ayam pedaging strain Cobb yang berumur 35 hari dari PT. Charoen Pokphand Indonesia. Kandang yang digunakan adalah kandang kecernaan yang berukuran 35 x 40 x $40 \mathrm{~cm}^{3}$ sebanyak 20 unit yang berisikan 1 ekor ayam. Perlengkapan yang digunakan yaitu tempat makan dan minum, thermometer untuk mengukur suhu, lampu penerang, alumunium foil, selotip, detol untuk mencuci tempat makan dan minum, timbangan, kuas, baki untuk tempat penyimpanan ekskreta pada saat dijemur, spatula yang dipakai untuk mengangkat ekskreta, dan amplop kertas untuk menyimpan sampel yang dianalisis di laboratorium.

\section{Pakan Percobaan}

Pakan yang digunakan adalah pakan komersial dan pakan sumber serat yang terdiri dari kulit kopi, dedak padi dan ampas kelapa serta tepung ikan. Komposisi bahan penyusun pakan perlakuan tercantum pada Tabel 1 dan susunan pakan perlakuan tercantum pada Tabel 2. Standar kebutuhan yang digunakan mengacu pada kebutuhan ayam pedaging dari PT. Charoen Pokphand. Pakan komesial yang digunakan adalah CP 12.

\section{Metode Penelitian}

Metode percobaan menggunakan Rancangan Acak Lengkap (RAL) (Steel and Torrie, 1991). Perlakuan yang digunakan adalah R0 (pakan komersial), R1 (pakan komesial dengan kulit kopi), R2 (pakan komesial dengan dedak padi), dan R3 (pakan komesial dengan ampas kelapa). Setiap perlakuan diulang 5 kali.

\section{Prosedur Penelitian}

Penempatan ayam ke kandang perlakuan didasarkan pada bobot badan yang seragam. Penimbangan sisa konsumsi dilakukan setiap pagi. 4 hari periode pendahuluan atau adaptasi ransum 
Tabel 1. Komposisi Bahan Penyusun Pakan Perlakuan

\begin{tabular}{lccccccc}
\hline Bahan Pakan & $\begin{array}{c}\text { BK } \\
(\%)\end{array}$ & $\begin{array}{c}\text { PK } \\
(\%)\end{array}$ & $\begin{array}{c}\text { LK } \\
(\%)\end{array}$ & $\begin{array}{c}\text { SK } \\
(\%)\end{array}$ & $\begin{array}{c}\text { Ca } \\
(\%)\end{array}$ & $\begin{array}{c}\text { P } \\
(\%)\end{array}$ & $\begin{array}{c}\text { EB } \\
(\text { Kkal })\end{array}$ \\
\hline CP12* & 87,00 & 20,00 & 5,00 & 5,00 & 0,90 & 0,60 & 2965 \\
Kulit Kopi** & 88,69 & 16,72 & 7,06 & 20,02 & 0,23 & 0,02 & 3063 \\
Dedak Padi*** & 85,59 & 7,91 & 5,91 & 23,37 & 0,22 & 0,95 & 2788 \\
Ampas Kelapa**** & 88,69 & 11,35 & 23,36 & 14,97 & 0,11 & 0,47 & 3279 \\
Tepung Ikan*** & 92,16 & 59,91 & 9,34 & 0,90 & 7,04 & 3,67 & 3851 \\
\hline
\end{tabular}

Keterangan: BK: bahan kering, PK: protein kasar, LK: lemak kasar, Ca: calsium, P:phospor, SK: serat kasar, EB: energi bruto,

Sumber: "PT. Charoen Phokphand, ${ }^{* *}$ Tulung et al. (2015), ${ }^{* * *}$ Londok et al. (2017), ${ }^{* * * *}$ Putri (2010).

Tabel 2. Komposisi Pakan Perlakuan, Kandungan Zat-zat Makanan dan Energi

\begin{tabular}{lllll}
\hline Perlakuan & R0 & R1 & R2 & R3 \\
\hline Ransum komersial & 100 & 62 & 58 & 34 \\
Kulit kopi & 0 & 35 & 0 & 0 \\
Dedak padi & 0 & 0 & 32 & 0 \\
Ampas kelapa & 0 & 0 & 0 & 54 \\
Tepung ikan & 0 & 3 & 10 & 12 \\
\hline Total & 100 & 100 & 100 & 100 \\
\hline BK & 87,00 & 84,98 & 87,06 & 88,53 \\
Protein $(\%)$ & 20,00 & 19,96 & 19,82 & 19,76 \\
Serat kasar(\%) & 5,00 & 10,13 & 10,47 & 9.89 \\
Lemak $(\%)$ & 5,00 & 5,85 & 5,73 & 15,44 \\
Ca $(\%)$ & 0,90 & 0,85 & 1,30 & 1,21 \\
P $(\%)$ & 0,60 & 0,49 & 1,02 & 0,90 \\
EM (Kkal) & 2965 & 3026 & 2997 & 3241 \\
\hline Kerangan & Cih & & & \\
\hline
\end{tabular}

Keterangan : dihitung berdasarkan Tabel 1

diberikan ad libitum dan pemberian air minum setelah ditimbang menggunakan air gula merah dengan tujuan menghindari stres pada ayam, air minum disediakan bebas. Pada periode pengambilan data, jumlah pakan yang diberikan sebanyak $80 \%$ dari rata-rata konsumsi pada periode pendahuluan yang bertujuan agar tidak ada sisa pemberian pakan pada ayam. Pada setiap defikasi ekskreta disemprot dengan $\mathrm{H}_{2} \mathrm{SO}_{4}$. Kecernaan dihitung dengan metode total koleksi yaitu setiap harinya setelah 24 jam ekskreta yang dihasilkan ayam dari hari pertama pengambilan data sampai hari terakhir pada pagi hari ditampung kemudian dijemur sampai kering. Setelah kering dilanjutkan dengan penimbangan untuk mengetahui berat kering, kemudian digiling dan penggilingan dilakukan dengan mencampur ekskreta dari hari pertama sampai hari ketiga dengan sumber serat yang sama dicampur agar homogen. Sampel ekskreta diambil secara komposit sebanyak 50 gram, untuk keseragaman 
sampel, dilakukan dengan pengambilan sampel pada setiap bagian. Dilanjutkan dengan analisa kandungan serat kasar dan hemiselulosa di laboratorium Ilmu Nutrisi dan Teknologi Pakan Falultas Peternakan IPB. Bogor.

\section{Peubah yang diukur}

1. Penentuan Konsumsi Serat Kasar (SK)

Konsumsi SK $=\frac{S K \text { Analisis }}{100} \times$ Konsumsi

Keterangan:

SK Analisis = Jumlah Serat kasar dalam ransum hasil analisis

Konsumsi $=$ Jumlah pakan yang dikomsumsi

2. Penentuan kecernaan Serat Kasar (Prawitasari et al, 2012)

Kecernaan serat $\operatorname{kasar}(\%)=$

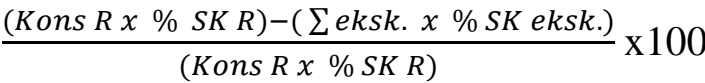

Keterangan :

Kons $\mathrm{R}=$ Jumlah pakan yang dikonsumsi

SK R = Serat kasar ransum (\%)

$\sum$ ekskreta $=$ Jumlah ekskreta yang di defikasi

SK ekskreta=Serat kasar ekskreta (\%)

3. Penentuan kecernaan Hemiselulosa (Van Soest, 1994)

Kecernaan hemiselulosa $(\%)=$

(Kons R $x \%$ hemiselulosa $)-($ ( eksk. $x \%$ hemiselulosa eksk) (Kons R $x \% S K R$ )

Keterangan :

Kons $\mathrm{R}=$ Jumlah pakan yang dikonsumsi $\sum$ ekskreta $=$ Jumlah ekskreta yang di defikasi

\section{Analisis Data}

Keseluruhan data yang terkumpul dianalisis menggunakan ANOVA pada aplikasi MINITAB versi 16. Perbedaan nilai tengah kombinasi perlakuan duji dengan uji beda nyata jujur (BNJ) menggunakan Tukey Simultaneous Test, pada tingkat nyata $95 \%(\mathrm{P}<0.05)$ dan $99 \%$ $(\mathrm{P}<0,01)$,

\section{HASIL DAN PEMBAHASAN}

Rataan yang diperoleh dari kecernaan serat kasar dan kecernaan hemiselulosa selama penelitian berlangsung dapat dilihat pada Tabel 3.

\section{Pengaruh Perlakuan terhadap Konsumsi Serat Kasar}

Rataan konsumsi serat kasar dalam penilitian ini dapat dilihat pada Tabel 3, dimana rataannya berkisar antara 7,65\% sampai $10,74 \%$ dilihat pada Tabel 3, dimana rataan tertinggi terdapat pada perlakuan R1 (pakan tepung kulit kopi) dan terendah pada perlakuan R0 (pakan komersial). Berdasarkan analisis ragam (ANOVA) menunjukkan bahwa perlakuan memberikan pengaruh yang sangat nyata $(\mathrm{P}<0,05)$ terhadap konsumsi serat kasar. Uji BNJ menunjukkan bahwa perlakuan R1 berbeda sangat nyara $(\mathrm{P}<0,01)$ dengan perlakuan R3, R2, dan R0. Perlakuan R3 berbeda tidak nyata $(\mathrm{P}>0,05)$ dengan perlakuan R2 tetapi berbeda sangat nyata $(\mathrm{P}<0,01)$ dengan perlakuan R0. Perlakuan $\mathrm{R} 2$ berbeda sangat nyata $(\mathrm{P}<0,01)$ dengan 
Tabel 3. Rataan Kecernaan Semu Serat Kasar dan Hemiselulosa Pakan Ayam Pedaging Strain Cobb

\begin{tabular}{lcccc}
\hline \multirow{2}{*}{ Variabel } & \multicolumn{3}{c}{ Perlakuan } \\
\cline { 2 - 5 } & $\mathrm{R} 0$ & $\mathrm{R} 1$ & $\mathrm{R} 2$ & $\mathrm{R} 3$ \\
\hline Konsumsi serat kasat $\left(\mathrm{g} \mathrm{ekor}^{-1}\right.$ hari $\left.^{-1}\right)$ & $7,65^{\mathrm{c}}$ & $12,22^{\mathrm{a}}$ & $9,82^{\mathrm{b}}$ & $10,74^{\mathrm{b}}$ \\
Kecernaan Searat Kasar $(\%)$ & $45.66^{\mathrm{a}}$ & $15.26^{\mathrm{b}}$ & $24.83^{\mathrm{b}}$ & $42.92^{\mathrm{a}}$ \\
Kecernaan Hemiselulosa (\%) & $68,17 \mathrm{a}$ & $41,39^{\mathrm{b}}$ & $44,70^{\mathrm{b}}$ & $71,80^{\mathrm{a}}$ \\
\hline Keterangan: Superskrip berbeda pada baris yang sama menunjukkan perbedaan nyata $(\mathrm{P}<0,05)$.
\end{tabular}

R0. Konsumsi pakan meningkat karena meningkatnya serat kasar yang berpengaruh pada semakin cepatnya laju pakan. Serat kasar dalam pakan unggas memiliki manfaat membantu peristaltik memacu perkembangan organ pencernaan, dan juga serat kasar yang tinggi menyebabkan unggas merasa kenyang, yang bisa mengurangi konsumsi karena serat kasar sangat banyak (Londok dan Rompis, 2019). Golian dan Maurice (1991) menyatakan bahwa serat kasar yang tinggi dalam pakan mengakibatkan laju pakan semakin cepat karena diikuti dengan konsumsi air minum untuk menyeimbangi serat kasar yang bersifat bulky. Sehingga untuk konsumsi serat kasar pada perlakuan R1 (pakan dengan kulit kopi) lebih tinggi disebabkan karena kandungan serat kasar yang lebih tinggi dari perlakuan yang lain. Kandungan zat nutrisi yang terdapat pada kulit buah kopi seperti protein kasar sebesar $10,4 \%$, serat kasar sebesar $17,2 \%$ dan energi metabolis 14,34 MJ/kg (Zainuddin dan Murtisari, 1995). Kulit kopi juga memiliki zat anti nutrisi yaitu tanin, tanin memiliki efek gangguan bagi pertumbuhan ternak bila ditambahkan ke dalam pakan dalam jumlah yang banyak (Porres et al., 1993).

\section{Pengaruh Perlakuan terhadap Kecernaan Semu Serat Kasar Pakan}

Rataan kecernaan serat kasar berkisar antara 15,26 sampai 45,66\% dilihat pada Tabel 3, dimana angka kecernaan tertinggi terdapat pada perlakuan R0 (pakan komersial) dan terendah pada R1 (pakan dengan kulit kopi). Berdasarkan analisis ragam (ANOVA) menunjukkan bahwa pemberian pakan komersial dan pakan dengan sumber serat kasar yang berbeda memberikan pengaruh yang sangat nyata $(\mathrm{P}<0,01)$ terhadap kecernaan semu serat kasar pakan. Uji BNJ menunjukkan bahwa perlakuan $\mathrm{R} 0$ berbeda tidak nyata $(\mathrm{P}>0,05)$ dengan perlakuan R3 tetapi berbeda sangat nyata $(\mathrm{P}<0,01)$ dengan $\mathrm{R} 2$ dan $\mathrm{R}$ 1. Perlakuan R2 berbeda tidak nyata $(\mathrm{P}>0.05)$ dengan R1. Perlakuan pakan yang mengandung ampas kelapa lebih tinggi kecernaan seratnya dibandingkan dengan 
pakan yang mengandung dedak padi dan kulit kopi. Hal ini diduga karena perbedaan komponen serat dari masing-masing sumber serat. Purawisastra (2001), menyatakan bahwa pakan ampas kelapa mengandung galaktomanan sebesar $61 \%$. Galakatomanan adalah polisakarida yang terdiri dari rantai mannose dan galaktosa, senyawa ini bermanfaat bagi kesehatan ternak karena mengandung serat dan polisakarida, juga berperan memicu pertumbuhan bakteri usus yang membantu pencernaan (Yamin, 2008).

\section{Pengaruh Perlakuan terhadap Kecernaan Hemiselulosa Pakan}

Rataan kecernaan hemiselulosa dalam penelitian ini dapat dilihat pada Tabel 3, dimana rataannya berkisar antara 41,39 sampai 71,80\%. Rataan kecernaan semu hemiselulosa pakan tertinggi ditunjukkan oleh perlakuan R3 (pakan dengan ampas kelapa), sedangkan terendah ditunjukkan oleh perlakuan R1 (pakan dengan kulit kopi). Hasil analisis ragam (ANOVA) menunjukkan bahwa perlakuan memberikan pengaruh yang sangat nyata $(\mathrm{P}<0.01)$ terhadap angka kecernaan semu hemiselulosa pakan. Uji BNJ menunjukkan bahwa R3 sama dengan R0, namun berbeda sangat nyata $(\mathrm{P}<0.01)$ dengan perlakuan $\mathrm{R} 2$ dan R1. Perlakuan R2 berbeda tidak nyata ( $>0.05)$ dengan perlakuan R1.
Kadar hemiselulosa diperoleh dari perhitungan selisih antara NDF (Netral Detergent Fiber) dan ADF (Acid Detergent Fiber), sehingga penurunan kecernaan hemiselulosa disebabkan karena adanya penurunan kecernaan NDF dan ADF pada setiap perlakuannya, seperti yang dinyatakan oleh Tillman et al. (1998) bahwa komponen fraksi yang mudah terdegradasi pada NDF adalah hemiselulosa. Halili (2014) menyatakan bahwa hemiselulosa rantainya pendek dibandingkan selulosa dan merupakan polimer campuran dari berbagai senyawa gula seperti galaktosa. Selain itu, umumnya hemiselulosa larut dalam alkali dengan kosentrasi rendah, dimana semakin banyak cabangnya semakin tinggi kelarutannya. Hemiselulosa dapat dihidrolisis dengan enzim hemiselulase. Van Soest (1985) menyatakan bahwa daya cerna dan tingkat kecernaan hemiselulosa lebih tinggi dibandingkan dengan selulosa. Hal tersebut dikarenakan senyawa penyusun serat kasar, hanya selulosa, lignin dan silika yang sulit untuk dicerna oleh unggas, sedangkan hemiselulosa masih dapat dihidrolisis oleh kandungan asam di dalam proventikulus dan rempela. Scott et al. (1982) melaporkan bahwa percobaan dengan menggunakan ayam mengindikasikan bahwa ayam mendapat energi dari hemiselulosa melalui proses hidrolisis yang mungkin terjadi dalam kondisi asam di dalam proventikulus 
dan rempela, atau mungkin adanya pencernaan oleh mikroba dalam usus sehingga menghasilkan energi. Karbohidrat utama di dalam dedak padi adalah hemiselulosa $(8,7-11,4 \%$, selulosa 9 $12,8 \%$, pati $5-15 \%$ dan $\beta$-glucan $1 \%$ ).

\section{KESIMPULAN}

Ampas kelapa sebagai sumber serat dalam pakan ayam pedaging strain cobb memberikan kecernaan serat kasar dan hemiselulosa yang lebih baik dari pada sumber serat kulit kopi dan dedak padi.

\section{DAFTAR PUSTAKA}

Golian, A dan D.V Maurice. 1991. Effect of dietary factors on gastrointinal transit time (GTT) of food in laying hens. Poultry Science 70:45

Halili, A. 2014. Kandungan Selulosa, Hemiselulosa Dan Lignin Pakan Lengkap Berbahan Jerami Padi. Skiripsi. Fakultas Peternakan Universitas Hasanuddin, Makasar.

Londok, J.J.M.R., W. Manalu, K.G. Wiryawan, dan Sumiati. 2017. Growth performance, carcass characteristics and fatty acids profile of broiler supplemented with lauric acid and natural antioxidant from area vestiaria Giseke. Pak. J. Nutr 16(9): 719-730.

Londok, J.J.M.R. dan J.E.G. Rompis. 2019. Supplementation of lauric acid and feed fiber to optimize the performance of broiler. IOP Conf. Series: Earth and Enviromental Science 387:1-4.
Muhammad, K.U., S.P. Heny dan V.M. Ani. 2014. Produksi ayam pedaging strain cobb. Jurnal Ilmu-ilmu Peternakan 24(3):79-87.

Prawitasari, R. H., V.D.Y.B. Ismadi dan I. Estiningdriati. 2012. Kecernaan protein kasar dan serat kasar serta laju digesta pada ayam arab yang dibei ransum dengan berbagai level Azolla microphylla. Animal Agriculture Journal 1(1):471-483.

Porres, C., D. Alvares dan Calzada. 1993. Caffeine roduction incoffe pulp trough silage. J Biotechnology Advantages. 11:519-521.

Purawisastra, S. 2001. Pengaruh isolat galaktomannan kelapa terhadap kadar kolesterol. Center for Research and Development of nutrition and Food. Badan Litbang Kesehatan. Jakarta. Hal 1-10.

Putri, M. F. 2010. Tepung ampas kelapa pada umur panen 11-12 sebagai bahan pangan sumber kesehatan. Jurnal Kompetensi Teknik 1:97-105.

Scott, M. L., M.C. Nesheim, dan R. J. Young. 1982. Nutrision of Thechickens. 3 ed. M. L. Scott and Associates. Ithaca, New York.

Steel, R. G. D. dan J. H. Torrie. Prinsip Dan Prosedur Statistika. Alih bahasa, Ir. Bambang Sumantri (Institut Pertanian Bogor). PT Gramedia, Jakarta.

Tillman, A.D., H. Hartadi, S. Reksohadiprodjo, S. Prawirokusumo dan S. Lebdosoekojo. 1998. Ilmu Makanan Ternak Dasar. Gadjah Mada University Press, Yogyakarta.

Tulung, B., J.J.M.R. Londok dan M.R. Regar. 2015. The effect of length of feeding and level of crude fiber, carcass quality and serum cholesterol of broiler chicken. Proceding. The 
4nd Internasional Seminar of AINI. Faculty of Animal Husbandry, Sam Ratulangi University. Manado.

Van Soest, P. J. 1985. Definition of Fiber in Animal Feeds.In : Cole, D. J. A.. and W. Haresign (ed.). Recent Advances in Animal Nutrition. Butterworths, London.

Van Soest, P.J. 1994. Nutritional Ecology of The Ruminant. 2nd ed. Comstock Publishing Associates. A. Division of Cornell University Press. Ithaca and London.

Yamin, M. 2008. Pemanfaatan ampas kelapa dan ampas kelapa fermentasi dalam ransum terhadap efisiensi ransum dan Income Over Feed Cost ayam pedaging. Jurnal Agroland 15(2):135-139.

Zainuddin, D. dan T. Murtisari. 1995. Penggunaan limbah agro-industri buah kopi (kulit buah kopi) dalam ransum ayam pedaging (broiler). Prosiding. Pertemuan Ilmiah Komuikasi dan Penyaluran Hasil Penelitian. Sub Balai Penelitian Klepu, Puslitbang Peternakan, Bogor. Hlm 71-78. 